\title{
Aikuiskasvatuksen filosofiset perusteet
}

John L. Elias \& Sharan B. Merriam (2005). Philosophical Foundations of Adult Education. 3. laitos. Malabar: Krieger. 286 s.

\begin{abstract}
$\mathrm{J}$ ohn L. Elias ja Sharan Merriamin kirjoittama aikuiskasvatuksen filosofisia perusteita tarkasteleva teos julkaistiin ensimmäisen kerran 1980. Toinen laitos tuli viisitoista vuotta myöhemmin ja 2005 ilmestyi kolmas, uudistettu laitos. Kirjan eri laitoksia on käytetty meilläkin oppikirjoina, jollaisena ne ovat toimineet hyvin.
\end{abstract}

Kirjoittajista John L. Elias on uskonto- ja kasvatustieteen professori Fordhamin yliopistossa New Yorkissa ja kirjoittanut aiemmin muun muassa Paulo Freiren vapautuksen pedagogiikasta. Sharan B. Merriam, toimii aikuiskasvatuksen professorina Georgian yliopistossa Athensissa Yhdysvalloissa. Hän on ollut tuottelias kirjoittaja julkaisten muun muassa tapaustutkimuksen metodikirjoja. Hänen haastattelunsa on julkaistu Aikuiskasvatus-lehdessä 2/95.

Teoksessa esitellään omina lukuinaan liberaali, progressiivinen, behavioristinen, humanistinen, radikaali ja kriittinen, analyyttinen ja postmoderni aikuiskasvatuksen filosofia. Niitä ennen lukija johdatetaan kirjan tarkastelutapaan ja määritellään filosofian käsitettä sekä erityisesti sitä, mitä filosofia tarkoittaa aikuiskasvatuksen ja sen monimuotoisten käytäntöjen kannalta. Lukuun on liitetty myös jäljessä tulevien lyhyet luonnehdinnat.

Tekijät näyttävät painottavan käsitystä, jonka mukaan aikuiskasvattaja aikuiskasvatuksen filosofiaa tarvitaan ennen kaik- kea tulkinnallisena työvälineenä, joka antaa laajakuvan alan erilaisista perinteistä ja niiden oletuksista. Tarkoitus ei ole ollut tyrkyttää jotakin tiettyä aikuiskasvatuksen filosofiaa, vaan kirjoittaa alamme filosofioiden yleiskuva. Silti kysymys on aina valinnoista, näkökulmista ja tulkinnoista. Kaiken kattava kirjoitustapa on luonnollisesti mahdoton.

Kirja on kirjoitettu selkeällä kielellä, se ole mitenkään vaikeatajuinen eikä sisällä mitään sellaista, mikä estäisi sen käytön kurssikirjana jo aikuiskasvatukseen johdattavissa opinnoissa. Tähän asti aikuiskasvatuksen perusopinnoissa, etenkin avoimen yliopiston puolella, on karsastettu vieraskielistä kurssikirjallisuutta, mutta kielitaidon karttuessa tämäkin ongelma väistynee. Vinkki KVS:n kustannustoiminnasta vastaaville: toki kirjan uutta laitosta lukisi myös suomeksi vaikkapa alan suomalaisin tai pohjoismaisin näkökulmin täydennettynä.

Kirjoittajat ovat laitoksesta toiseen säilyttäneet kirjansa perusrakenteen, mutta tarkistaneet sisältöä jokaisella kerralla. Uuteen laitokseen he ovat tehneet aiempia perusteellisemman uudistuksen. Ratkaisu on toimiva. Kirjan rakenne on kestänyt hyvin uuden muokkauksen.

Vuoden 1995 laitokseen tekijät kirjoittivat jälkipuheen, jossa päivitettiin kirjan ensimmäistä painosta. Ratkaisu ei tyydyttänyt sen paremmin tekijöitä kuin lukijoita, sillä perustekstiin jäi osin vanhentunutta asiaa, joka oli ristiriidassa uusien tulkintojen kanssa. Uudessa laitoksessa jälkipuheesta on luovuttu ja nyt sen asiat on laajentaen siirretty kahteen lukuun: radikaalia aikuiskasvatusta koskevassa luvussa on mukana kriittistä pedagogiikkaa tarkasteleva osuus. Omaksi kokonaisuudekseen on lisätty postmodernismi ja aikuiskasvatusta kuvaileva luku. Tämä ratkaisu on hiukan jälkijättöinen, sillä aihe olisi tietenkin pitänyt olla esillä jo kirjan edellisessä laitoksessa.

Kirjan pääluvuissa johdatetaan aiempien laitosten tapaan perusteellisesti eri suuntausten lähtökohtiin ja keskeisiin edustajiin sekä tarjotaan täydennettyjä kirjallisuusviitteitä, joista lukija pääsee eteenpäin. Mutta mitä kirjan eri laitoksia vertailemalla voi päätellä aikuiskasvatuksen filosofiassa tapahtuneista painotuksista? Onko kuluneissa 25 vuodessa tapahtunut mitään? Kyllä on, aikuiskasvatuksen filosofinen ymmärrys on laajentunut ja aiemmat tieteenfilosofiset lähtökohdat on kyseenalaistettu.

Postmodernien näkemysten myötä tutkijat ovat siirtyneet objektivistisesta ja yksiulotteisesta tiedenäkemyksestä relationalistisiin ja moni-ilmeisempiin tulkintoihin. Relationaalisuus eli suhteissa oleminen ja suhteiden kautta ymmärtäminen, tarkoittaa aikuiskasvatuksen filosofian juurruttamista erilaisiin ajatteluperinteisiin ja käytäntöihin, ja toisaalta näiden perinteiden näkemistä aikuiskasvatuksen filosofioiden läpi. Relationalismi on merkinnyt aikuiskasvatuksen 
filosofian sukupuolittumista. unohtamatta. Myös monikultEntinen heteronormatiivisuus on saanut rinnalleen monimuotoisia mies- ja naisnäkökulmia ja lisäksi seksuaalisilla vähemmistöillä on omat aikuiskasvatuksen filosofiansa. Toisaalta aikuiskasvatuksen tutkijat ovat siirtyneet psykologisesta suuntautumisesta yhteiskuntatieteelliseen ja kriittiseen orientaatioon. Tämä on tarkoittanut ilmiöiden tarkastelemista aiempaa enemmän yhteiskunnallisissa yhteyksissä yhteiskuntaluokan käsitettä tuurisuus ja etnisyys ovat tulleet maailmankuvan eroista kertoviksi teemoiksi aikuiskasvatuksen filosofiaan.

Kirjan näkökulma on luonnollisesti edelleen pohjoisamerikkalainen, ja se näkyy myös runsaissa englanninkielisissä lähteissä. Mutta näiden rinnalla käsitellään myös mannermaista ja latinalaisamerikkalaista aikuiskasvatusajattelua. Esillä on niin saksalainen kriittinen teoria kuin Paulo Freiren sorrettujen peda- gogiikka. Pohjoismaisesta perinteestä ei juurikaan kirjoiteta, kuten ei monista muistakaan yhdysvaltalaisille kenties vähämerkityksisiltä vaikuttavista kulttuuritraditioista. Silti kysymyksessä on kattavanoloinen peruskirja, jota lukiessa voi miettiä, mitä muuta aikuiskasvatuksen filosofiaan voisi vielä liittää?

\section{Juha Suoranta}

